\title{
A Scoping Review of Psychological Interventions for PTSD in Military Personnel and Veterans
}

\section{Stephen Rose, Alice Aiken \& Mary Ann McColl}

To cite this article: Stephen Rose, Alice Aiken \& Mary Ann McColl (2014) A Scoping Review of Psychological Interventions for PTSD in Military Personnel and Veterans, Military Behavioral Health, 2:3, 264-282, DOI: 10.1080/21635781.2014.963757

To link to this article: http://dx.doi.org/10.1080/21635781.2014.963757

Accepted author version posted online: 15

Sep 2014.

Submit your article to this journal

Џ Article views: 673

Q View related articles $₫$

View Crossmark data 


\title{
A Scoping Review of Psychological Interventions for PTSD in Military Personnel and Veterans
}

\author{
Stephen Rose, Alice Aiken, and Mary Ann McColl \\ Queen's University, Kingston, Ontario, Canada
}

\begin{abstract}
Post-traumatic stress disorder (PTSD) has emerged as a key concern for military and veteran populations. This article describes what is being done programmatically and therapeutically to treat PTSD in military personnel and veterans returning from deployment. This scoping review demonstrates that (1) research published in this area has been rapidly increasing since its inception in the 1980s; (2) the vast majority of articles focus on cognitive-behavioral approaches to treatment, and this area of the literature presents strong evidence for these approaches; and (3) there is a lack of randomized controlled trials for treatments, such as art therapies and group therapies.
\end{abstract}

Keywords: PTSD, Post-traumatic stress, military, veterans, scoping review, evidence-based medicine, intervention, therapy, program, cognitive-behavioral

\section{INTRODUCTION}

There is an increasing awareness of problems resulting from war trauma. Since its initial DSM-III formulation in 1980, post-traumatic stress disorder (PTSD) has gained considerable attention in the literature concerning its treatment. In the introduction to their edited collection, Effective Treatments for PTSD (Second Edition), Edna B. Foa, Terence M. Keane, Matthew J. Friedman, and Judith A. Cohen (2010) state that quality studies on interventions for PTSD have been increasing rapidly in the past 25 years. Although psychotherapeutic and pharmacological interventions both characterize this literature, the present scoping review focuses only on the psychotherapeutic literature.

Although a growing number of quality studies are assessing the effectiveness of psychotherapeutic interventions for PTSD, this evidence is often not put into practice. An analysis of U.S. Veterans Health Administration outpatient PTSD clinics in New England found that only 6.3\% of the study population received at least one session of evidence-based psychotherapy during their initial six months in treatment (Shiner et al., 2013). In the Canadian context,

Address correspondence to Stephen Rose, Department of Sociology, Queen's University, Mackintosh-Corry Hall, 99 University Ave, Kingston, Ontario, K7L 3N6 Canada. E-mail: s.rose@ queensu.ca

Color versions of one or more of the figures in the article can be found online at www.tandfonline.com/umbh.
Monson (2013) states that "research suggests that a minority of clinicians provide evidence-based therapies in clinical settings." To improve the lives of those affected with PTSD, it is important that research is available and utilized by clinicians.

The purpose of our research is to review the international academic literature for psychotherapeutic treatments for PTSD in veterans and military personnel. The main contribution of this research is to provide a characterization of a large number of studies on various types of psychotherapeutic treatments. By evaluating the quality of methodological support for various treatments, this study goes beyond the scope of a typical meta-analysis which focuses solely on high-quality studies for a specific treatment only. Without restricting the study to a specific treatment or methodological orientation, this scoping review provides a broader overview of the recent rapid development of literature on psychotherapeutic interventions for PTSD. Along with providing a map of the literature for clinicians in the area, this scoping review provides recommendations for future research by showing which psychotherapeutic interventions are receiving significant attention in terms of antidotal evidence but lacking support from studies with a more rigorous methodology. The unique contribution of this scoping review is descriptive and prescriptive; it provides a topological overview characterizing the literature in this area, as well as suggesting areas where future research can be done. 
This review primarily assesses six major areas of research: cognitive-behavioral therapies, group therapies, distance therapies, relaxation therapies, art therapies, and novel therapies.

Cognitive-behavioral therapies are most prominent in the literature on therapeutic interventions for PTSD in military and veteran populations. The major forms of cognitive-behavioral therapies in this study include prolonged or direct therapeutic exposure, virtual reality, and cognitive processing therapy. Prolonged or direct therapeutic exposure consists of exposing the patient to distressing stimuli at increasing intervals over a prolonged period of several months to several years within and outside of therapy sessions. Virtual-reality exposure uses this same technique but simulates the distressing stimulus using the vivid sensations produced within a virtual environment. Sensations include sights, sounds, and even scents associated with distressing stimuli, such as explosions and gunfire. Cognitive-processing therapy uses the same principle of reducing avoidance through confronting distressing stimuli but operates on the more abstract level of confronting distressing mental representations. This form of therapy teaches patients cognitive tools that allow them to modify the meaning attributed to a trauma so that they can understand the event within its original context.

\section{METHODS}

This study employs a scoping review approach to scan an extensive body of literature to determine how the research question is addressed in the literature. According to Arksey \& O'Malley (2005) the scoping review unfolds in five stages: (1) identify the research questions, (2) identify relevant studies, (3) determine and apply inclusion and exclusion criteria, (4) chart the data, and (5) summarize and report the results (Levac, Colquhoun, \& O'Brien, 2010). This study is guided by the following research question: What are the current psychotherapeutic treatments for PTSD in veterans and military personnel?

The literature search covered indexed, published, peerreviewed literature from 1980 to 2013. The databases consulted include MEDLINE, EMBASE, and PsycINFO. Search strategies included the following keywords: military, veteran, PTSD, treatment, program, and therapy. The following specific psychotherapeutic treatments were also included as keywords: music therapy, occupational therapy, virtual reality exposure therapy, behaviour therapy, relaxation therapy, cognitive therapy, and psychoanalytic therapy. Combined into various search strategies, these keywords yielded 5,141 search results. Of these results 1,439 were duplicates, bringing the total search yield to 3,702 new results from the aforementioned databases. Results included journal articles, dissertations, latters to the journal editor, and book chapters.

Articles were excluded from this study by reviewing the titles, abstracts, and body of the text for relevance. Articles were excluded if they did not focus on veterans or military personnel, or did not focus on the assessment of a psychotherapeutic intervention for PTSD. After applying the exclusion criteria, 284 articles were included in this study.

Articles were then charted based on the following categories: author, title, year of publication, specific type of intervention, country of the study, population studied, and journal of publication, methods used, and conclusions of the study. When charting the data, six therapeutic themes emerged: cognitive-behavioral therapies, group therapies, distance therapies (i.e., telephone based), art therapies, relaxation therapies, and other therapies (novel interventions without sufficient thematic clusters).

\section{RESULTS}

The results of this scoping review are based on the following criteria: (1) level of evidence, (2) year of publication, (3) nationality of population studied, and (4) therapeutic type. This allows for an overview of the growth of the literature in recent years, the main interventions receiving attention, and the strength of evidence supporting various treatments.

\section{Evidence for Interventions}

The levels of evidence presented here are based on the classifications of Sackett, Straus, Richardson, Rosenberg, and Haynes (2000):

TABLE 1

Publications by Intervention Type

\begin{tabular}{|c|c|c|c|c|c|c|}
\hline Intervention Type & Level 1 & Level 2 & Level 3 & Level 4 & Level 5 & Total \\
\hline Cognitive-behavioral therapies & 19 & 18 & 69 & 13 & 49 & $168(62 \%)$ \\
\hline Group therapies & 2 & 2 & 7 & 1 & 18 & $30(11 \%)$ \\
\hline Distance therapies & 3 & & 3 & & 7 & $13(5 \%)$ \\
\hline Relaxation therapies & 2 & & 3 & & 5 & $10(4 \%)$ \\
\hline Art therapies & & & & 4 & 4 & $8(3 \%)$ \\
\hline Novel therapies & 7 & 1 & 5 & 1 & 26 & $40(15 \%)$ \\
\hline
\end{tabular}


Level 1 evidence: Randomized clinical trials

Level 2 evidence: Quasi-experimental studies such as prospective studies, and non-randomized comparison groups

Level 3 evidence: Preexperimental studies, such as uncontrolled studies, posttest only designs

Level 4 evidence: Observational studies including case series, and historical/retrospective reviews

Level 5 evidence: Surveys, case reports, single-subject studies, and expert opinion

This ranking system, based on the work of Sackett and colleagues (2000), corresponds with that of the Oxford Centre for Evidence-Based Medicine (2009). Regarding evidence for therapies, level one evidence requires experiments to be randomized and controlled. Experiments that used a pre-post measure but lacked randomization in their control/ comparison group are labeled level two. Experiments that that lacked a control/comparison group or use a posttestonly design are labeled level three. Observational studies that rely on strictly retrospective patient chart reviews or case series are labeled level four. Last, level five studies consist of anecdotal evidence from either qualitative single-subject case studies or expert opinion. Each of the three reviewers came to a mutual agreement regarding each study's ranking. In the case of a differing view, the reviewers engaged in dialogue to come to mutual agreement.

\section{Publications by Year}

Figure 1 displays the number of publications per year from 2003 to June 2013 as categorized by level of evidence.

\section{Publications by Country}

Of the 284 studies in this review, 256 articles (roughly $90 \%$ ) focus on veterans or military personnel from the United States. Other countries include Australia (nine publications), Israel (six publications), Croatia (five publications), the Netherlands (two publications), and Canada, China, Columbia, Germany, Norway, and Portugal (one publication each).

\section{Publications by Intervention Type}

The literature in support of psychotherapeutic interventions is classified based on five broad thematic categories: Cognitive-behavioral therapies are the focus of 168 articles (refer to Appendix 1 for a full list of subcategories), group therapies are the focus of 30 articles, distance therapies (web or telephone based) are the focus of 13 articles, relaxation therapies are the focus of 10 articles, and art therapies are the focus of 8 articles (refer to Appendix 2).

There are also 43 articles that focus on 27 other therapies that do not fit into the five previously defined categories and do not form large or distinct clusters; these are listed as novel interventions in this article (refer to Appendix 3 for a full list of these therapies).

Table 1 contains a summary of articles that support the effectiveness of each major type of psychotherapeutic intervention in this review. Of the 269 articles listed in Table 1, 15 additional articles are not included because those studies do not support the effectiveness of psychotherapeutic interventions. See Appendix 4 for this group of studies; EMDR




particularly stands out in this literature as a treatment that has a significant amount of evidence against it.

\section{DISCUSSION}

Overall, our conclusions confirm the assertions of Foa and colleagues (2010) that quality studies on psychotherapeutic interventions for PTSD have been increasing rapidly in the past 25 years. Particularly since 2007, the number of studies published has grown sharply. Although only part of 2013 is represented in this study, the results for that year lead us to be optimistic about the growth in quality of studies, as a much larger proportion of level one studies were published in that partial year compared to all previous years.

\section{Cognitive-Behavioral Therapies}

Cognitive-behavioral therapy (CBT) received the vast majority of attention in the literature with roughly $62 \%$ of the articles dedicated to assessing the effectiveness of its various forms. Prominent forms of CBT that received attention in this literature include prolonged or direct therapeutic exposure (five level 1 studies), virtual-reality exposure (three level 1 studies), and cognitive processing (three level 1 studies).

\section{Group Therapies}

Group therapies composed roughly $11 \%$ of the total studies appearing in this review. Studies in this area were distinguished based on the attention given to the importance of group dynamics in healing from trauma. A prominent form of group therapy in this review includes spiritually integrated therapy (one level 1 and one level 2 studies). This is a group therapy focused on religious meaning making to reduce religious strain following a military-related trauma.

\section{Distance Therapies}

Distance therapies compose roughly $5 \%$ of the total studies appearing in this review. Studies in this area were distinguished based on their attention given to the effectiveness of therapeutic methods administered through telephone or webcam. The concept of "telemedicine" appeared to be a prominent label applied to these techniques in the literature. With three level 1 studies, therapies administered by telephone or webcam are shown to be effective and comparable to in-person treatments. Other benefits mentioned in the literature state the improved treatment access for rural veterans and the opportunity to potentially reduce treatment dropout rates.

\section{Relaxation Therapies}

Relaxation therapies compose roughly $3.5 \%$ of studies appearing in this review. Studies in this area were distinguished based on their attention given to methods of mental or physical relaxation. Prominent forms of relaxation therapies include guided imagery (one level 1 study), sleepfocused mind-body bridging (one level 1 study), and meditation-based stress-reduction (one level 3 and one level 5 study). Guided imagery includes a therapist's use of relaxing mental stimuli to guide the thoughts of the patient. Sleep-focused mind-body bridging includes the use of techniques that increase the patient's awareness of dysfunctional mental and physical states, such as self-centeredness, rumination, and body tension. The studies that focus on meditation-based stress reduction use the technique of mantra repetition and transcendental meditation.

\section{Art Therapies}

Art therapies compose roughly $3 \%$ of the studies appearing in this review. Prominent forms include group music therapy and drawing. All of the studies in this area had level 4 or level 5 evidence.

\section{Novel Therapies}

Novel therapies compose roughly $15 \%$ of the studies in this review. In all, 28 different therapies are studied in the 40 articles that compose this category. Therapies were classified as novel if they received attention in five or fewer articles. Most therapies in this category received attention in only one or two articles. Prominent therapies in this category include yoga (two level 1 studies) and canine-assisted therapy (five level 5 studies). Although canine-assisted therapy has only level five evidence, it stands out as a novel intervention because it appears five times, suggesting it is getting a significant amount of attention despite the lack of quality evidence. For a full list of novel therapies, see Appendix 3.

\section{CONCLUSION}

In conclusion, this scoping review has provided a characterization of the literature on psychotherapeutic interventions for PTSD among military and veteran populations. It has demonstrated the dramatic rise of research in this area in the past 10 years and that an extremely high proportion of these studies come from the United States. It has also demonstrated that the largest cluster of studies assess cognitivebehavioral therapies, followed by group therapies, distance therapies, relaxation therapies, and art therapies, as well as more recently popular smaller clusters of novel interventions, such as yoga and canine-assisted therapy. 
There are a large number of studies assessing cognitivebehavioral therapies, many employing a high methodological standard. Going forward, it would be beneficial to conduct a meta-analysis on cognitive-behavioral psychotherapeutic interventions for PTSD among military and veteran populations. Although group therapies, distance therapies, and relaxation therapies are gaining traction, they lack in a significant number of quality studies. Future research would benefit from investigating the added value of these therapies as adjuncts to a cognitive-behavioral treatment regimen. Art therapy is an area that completely lacks quality studies, mainly reporting single-subject case studies or expert opinion. Canine-assisted therapy is a novel therapeutic intervention that also showed a significant cluster of anecdotal evidence and expert opinion, having no quality studies. Experimental research is needed for both art therapy and canine-assisted therapy.

Overall, the explosion of research on psychotherapeutic interventions for PTSD among military and veteran populations demonstrates hope for the future of treatment. With quality studies on various cognitive-behavioral therapies paving the way for evidence-based intervention, we hope that other innovative therapies will follow.

\section{REFERENCES}

Arksey, H., \& O'Malley, L. (2005). Scoping studies: Towards a methodological framework. International Journal of Social Research Methodology, 8(1), 19-32. doi:10.1080/1364557032000119616

Foa, Edna B., Keane, Terence M., Friedman, Matthew J., \& Cohen, Judith A. (Eds.). (2010). Effective treatments for PTSD: Practice guidelines from the International Society for Traumatic Stress Studies. New York, NY: Guilford Press.

Levac, D., Colquhoun, H., \& O’Brien, K. K. (2010). Scoping studies: Advancing the methodology. Implementation Science, 5(69). doi:10.1186/1748-5908-5-69

Monson, C. (2013). Implementation of evidence-based psychotherapy for PTSD. ClinicalTrials.gov. Retrieved from http://clinicaltrials.gov/show/ NCT01861769

Oxford Centre for Evidence-Based Medicine. (2009, March). Levels of evidence. Retrieved from http://www.cebm.net/oxford-centre-evidencebased-medicine-levels-evidence-march-2009/

Sackett, D. L., Straus, S. E., Richardson, W. S., Rosenberg, W., \& Haynes, R. B. (2000). Evidence-based medicine. Toronto, Canada: ChurchillLivingston.

Shiner, B., D'Avolio, L. W., Nguyen, T. M., Zayed, M. H., Young-Xu, Y., Desai, R. A., ..., Watts, B. V. (2013). Measuring use of evidence based psychotherapy for posttraumatic stress disorder. Administration and Policy in Mental Health, 40(4), 311-318. 


\section{APPENDIX 1. SUMMARY OF EVIDENCE IN SUPPORT OF COGNITIVE-BEHAVIORAL INTERVENTIONS}

\begin{tabular}{|c|c|c|c|c|c|}
\hline Type of CBT & Level 1 & Level 2 & Level 3 & Level 4 & Level 5 \\
\hline Prolonged or direct therapeutic exposure & 12345 & 678 & 91011121314 & 15161718192021 & $\begin{array}{c}222324252627 \\
2829303132 \\
33\end{array}$ \\
\hline Virtual-reality exposure & 343536 & 37 & $\begin{array}{c}383940414243 \\
4445464748 \\
495051\end{array}$ & & $\begin{array}{r}525354555657 \\
5859606162 \\
6364656667\end{array}$ \\
\hline Imagery rehearsal & 68 & 69 & 707172 & 73 & 74757677 \\
\hline Cognitive processing & 787980 & 8182 & 83848586 & & \\
\hline Mindfulness based & 87 & & 888990 & & \\
\hline Behavioral activation & & & 9192 & & 93 \\
\hline EMDR* & 9495 & 969798 & 99 & 100101102103 & $\begin{array}{c}104105106107 \\
108109110\end{array}$ \\
\hline Group CBT** & 111 & 112 & $\begin{array}{c}113114115116 \\
117118119 \\
120121122 \\
123124125 \\
126127\end{array}$ & 128 & 129130131 \\
\hline Distance CBT & 132 & 133134135 & $\begin{array}{c}136137138 \\
139140141142\end{array}$ & & 143 \\
\hline Systematic desensitization & & & & & 144 \\
\hline Behavioral family therapy & & & & & 145 \\
\hline Behavioral activation + therapeutic exposure & & & 146 & & \\
\hline Couple's CBT & 147 & & 148149 & & \\
\hline Dialectical behavior therapy & & & & & 150 \\
\hline Emotional clarity and cognitive reappraisal & & & 151 & & \\
\hline Prolonged exposure + stress inoculation training & & & 152153 & & \\
\hline Cognitive-behavioral anger treatment & & 154 & & & \\
\hline Cognitive-behavioral therapy for insomnia & 155 & & 156157 & & \\
\hline Cognitive processing therapy + prolonged exposure therapy & & 158 & & & \\
\hline Holographic reprocessing & & & 159 & & \\
\hline Acceptance and commitment therapy & & 160 & & & 161 \\
\hline Imagery rescripting and reprocessing therapy & & & 162 & & \\
\hline Schema-focused therapy & & 163 & & & \\
\hline Trauma management therapy & & & 164165 & & 166 \\
\hline Adaptive disclosure & & & 167 & & \\
\hline Cognitive behavioral social rhythm therapy & & & 168 & & \\
\hline
\end{tabular}

Notes. $*$ EMDR $=$ Eye movement desensitization and reprocessing $; *$ CBT $=$ Cognitive-behavioral therapy.

APPENDIX 2. SUMMARY OF EVIDENCE FOR THE EFFECTIVENESS OF OTHER FORMS OF THERAPY

\begin{tabular}{|c|c|c|c|c|c|}
\hline Type of Intervention & Level 1 & Level 2 & Level 3 & Level 4 & Level 5 \\
\hline Group therapies & 169170 & 171172 & 173174175176177178179 & 180 & $\begin{array}{c}181182183184185186187 \\
188189190191192193 \\
194195196197198\end{array}$ \\
\hline Distance interventions & 199200201 & & 202203204 & & 205206207208209210211 \\
\hline Relaxation techniques & 212213 & & 214215216 & & 217218219220221 \\
\hline Art therapies & & & & 222223224225 & 226227228229 \\
\hline
\end{tabular}


APPENDIX 3. SUMMARY OF EVIDENCE FOR NOVEL INTERVENTIONS

\begin{tabular}{|c|c|c|c|c|c|}
\hline Intervention & Level 1 & Level 2 & Level 3 & Level 4 & Level 5 \\
\hline Acupoint tapping (adjunct to exposure) & & & & & 230 \\
\hline Adlerian natural high therapy & & & & & 231 \\
\hline Bright light therapy & 232 & & & & \\
\hline Canine-assisted therapy & & & & & 233234235236237 \\
\hline Emotional freedom techniques (adjunctive) & 238 & & 239 & & \\
\hline Existential therapy & & & & & 240 \\
\hline Family-based model & & & & 241 & 242 \\
\hline Gestalt therapy & & & & & 243 \\
\hline Hypnotherapy & 244 & & 245 & & 246247 \\
\hline Lifestyle management courses & & & & & 248 \\
\hline Logotherapy & & & & & 249250 \\
\hline Mantram repetition for spiritual wellbeing & & & 251 & & \\
\hline Mythological studies approach & & & 252 & & \\
\hline Nature adventure rehabilitation & 253 & & & & \\
\hline Outward bound experience & & & & & 254 \\
\hline Group physical activity program & & & & & 255 \\
\hline Psychodynamic psychotherapy & & & & & 256257258 \\
\hline Present-centered therapy & & & & & 259 \\
\hline Resilience-oriented intervention & 260 & & & & \\
\hline Spiritual reconciliation & & & & & 261 \\
\hline Strategic approach therapy & & & & & 262 \\
\hline Therapeutic recreation (river running) & & & & & 263 \\
\hline Time-limited psychotherapy & & 264 & & & \\
\hline Transcendental meditation & & & & & 265 \\
\hline Vietnam war memorial pilgrimage & & & 266 & & \\
\hline Visual-kinesthetic dissociation protocol & & & & & 267 \\
\hline Yoga & 268269 & & & & \\
\hline
\end{tabular}

\section{APPENDIX 4. EVIDENCE REPORTING THE INEFFECTIVENESS OR VERY LIMITED EFFECTIVENESS OF INTERVENTIONS}

\begin{tabular}{|c|c|c|c|c|c|}
\hline Intervention & Level 1 & Level 2 & Level 3 & Level 4 & Level 5 \\
\hline Acceptance and commitment therapy & & 270 & & & \\
\hline Adventure-based counseling and psychodrama & & 271 & & & \\
\hline Anger management & & & 272 & & \\
\hline Behavioral activation group therapy & & 273 & & & \\
\hline Direct therapeutic exposure & & & 274 & & \\
\hline EMDR & 275276 & & & 277 & 278279 \\
\hline Group therapy & & & & 280 & \\
\hline Imagery rehearsal & 281 & & & & \\
\hline Koach project & & & & & 282 \\
\hline Relaxation therapy & & & 283 & & \\
\hline Virtual reality exposure & & 284 & & & \\
\hline
\end{tabular}




\section{APPENDICES 1 THROUGH 4 REFERENCES}

1. Beidel, D. C., Frueh, B. C., Uhde, T. W., Wong, N., \& Mentrikoski, J. M. (2011). Multicomponent behavioral treatment for chronic combat-related posttraumatic stress disorder: A randomized controlled trial. Journal of Anxiety Disorders, 25(2), 224-231.

2. Keane, T. M., Fairbank, J. A., Caddell, J. M., \& Zimering, R. T. (1989). Implosive (flooding) therapy reduces symptoms of PTSD in vietnam combat veterans. Behavior Therapy, 20(2), 245-260.

3. Su, H., Wang, J. T., Lou, Z. S., \& Lu, H. T. (2007). Cognitive-exposure therapy for post-traumatic stress disorder. Journal of Clinical Rehabilitative Tissue Engineering Research, 11(39), 7783-7786.

4. Boudewyns, P. A., \& Hyer, L. (1990). Physiological response to combat memories and preliminary treatment outcome in vietnam veteran PTSD patients treated with direct therapeutic exposure. Behavior Therapy, 21(1), 63-87.

5. Schnurr, P. P., Friedman, M. J., Engel, C. C., Foa, E. B., Shea, M. T., Chow, B. K.,... Bernardy, N. (2007). Cognitive behavioral therapy for posttraumatic stress disorder in women: A randomized controlled trial. Journal of the American Medical Association, 297(8), 820-830.

6. Boudewyns, P. A., Hyer, L., Woods, M. G., Harrison, W. R., \& McCranie, E. (1990). PTSD among Vietnam veterans: An early look at treatment outcome using direct therapeutic exposure. Journal of Traumatic Stress, 3(3), 359-368.

7. Glynn, S. M., Eth, S., Randolph, E. T., Foy, D. W., Urbaitis, M., Boxer, L., \& Crothers, J. (1999). A test of behavioral family therapy to augment exposure for combatrelated posttraumatic stress disorder. Journal of Consulting and Clinical Psychology, 67(2), 243-251.

8. Thorp, S. R., Stein, M. B., Jeste, D. V., Patterson, T. L., \& Wetherell, J. L. (2012). Prolonged exposure therapy for older veterans with posttraumatic stress disorder: A pilot study. American Journal of Geriatric Psychiatry, 20 (3), 276-280.

9. Raj, J. J., Guajardo, J. M., Blount, T. H., Mintz, J., Klocek, J. W., \& Roache, J. D. (2013). Alcohol consumption during exposure therapy in veterans with PTSD and alcohol use disorder. Alcoholism: Clinical and Experimental Research, 37(Suppl. 2), 331A.

10. Wolf, G. K., Strom, T. Q., Kehle, S. M., \& Eftekhari, A. (2012). A preliminary examination of prolonged exposure therapy with Iraq and Afghanistan veterans with a diagnosis of posttraumatic stress disorder and mild to moderate traumatic brain injury. Journal of Head Trauma Rehabilitation, 27(1), 26-32.

11. Cigrang, J. A., Rauch, S. A. M., Avila, L. L., Bryan, C. J., Goodie, J. L., Hryshko-Mullen, A., \& Peterson, A. L. (2011). Treatment of active-duty military with PTSD in primary care: Early findings. Psychological Services, 8(2), 104-113.

12. Rauch, S. A., Defever, E., Favorite, T., Duroe, A., Garrity, C., Martis, B., \& Liberzon, I. (2009). Prolonged exposure for PTSD in a Veterans Health Administration PTSD clinic. Journal of Traumatic Stress, 22(1), 60-64.

13. Tuerk, P. W., Yoder, M., Grubaugh, A., Myrick, H., Hamner, M., \& Acierno, R. (2011). Prolonged exposure therapy for combat-related posttraumatic stress disorder: An examination of treatment effectiveness for veterans of the wars in Afghanistan and Iraq. Journal of Anxiety Disorders, 25(3), 397-403.

14. Yoder, M., Tuerk, P. W., Price, M., Grubaugh, A. L., Strachan, M., Myrick, H., \& Acierno, R. (2012). Prolonged exposure therapy for combat-related posttraumatic stress disorder: Comparing outcomes for veterans of different wars. Psychological Services, 9(1), 16-25.

15. McDevitt-Murphy, M. E. (2011). Significant other enhanced cognitive-behavioral therapy for PTSD and alcohol misuse in OEF/OIF veterans. Professional Psychology: Research and Practice, 42(1), 40-46.

16. Mueser, K. T., Yarnold, P. R., \& Foy, D. W. (1991). Statistical analysis for single-case designs: Evaluating outcome of imaginal exposure treatment of chronic PTSD. Behavior Modification, 15(2), 134-155.

17. Nathan, P. E. (2005). Bringing home the psychological immediacy of the Iraqi battlefield. Pragmatic Case Studies in Psychotherapy, 1(2), 1-3.

18. Pitman, R. K., Orr, S. P., Altman, B., Longpre, R. E., Poire, R. E., Macklin, M. L., ... Steketee, G. S. (1996). Emotional processing and outcome of imaginal flooding therapy in Vietnam veterans with chronic posttraumatic stress disorder. Comprehensive Psychiatry, 37(6), 409-418.

19. Bisson, J. I., \& Jones, N. (1995). Taped imaginal exposure as a treatment for post-traumatic stress reactions. Journal of the Royal Army Medical Corps, 141(1), 20-24.

20. Marshall, R. D., Carcamo, J. H., Blanco, C., \& Liebowitz, M. (2003). Trauma-focused psychotherapy after a trial of medication for chronic PTSD: Pilot observations. American Journal of Psychotherapy, 57(3), 374-383.

21. Nacasch, N., Foa, E. B., Fostick, L., Polliack, M., Dinstein, Y., Tzur, D., \& Zohar, J. (2007). Prolonged exposure therapy for chronic combat-related PTSD: A case report of five veterans. CNS Spectrums, 12(9), 690-695.

22. Frueh, B. C. (1995). Self-administered exposure therapy by a Vietnam veteran with PTSD. American Journal of Psychiatry, 152(12), 1831-1832.

23. Back, S. E., Killeen, T., Foa, E. B., Santa Ana, E. J., Gros, D. F., \& Brady, K. T. (2012). Use of an integrated therapy with prolonged exposure to treat PTSD and comorbid alcohol dependence in an Iraq veteran. American Journal of Psychiatry, 169(7), 688-691.

24. Cigrang, J. A., Peterson, A. L., \& Schobitz, R. P. (2005). Three American troops in Iraq: Evaluation of a brief exposure therapy treatment for the secondary prevention of 
combat-related PTSD. Pragmatic Case Studies in Psychotherapy, 1(2), 1-25.

25. Duax, J. M., Waldron-Perrine, B., Rauch, S. A. M., \& Adams, K. M. (2013). Prolonged exposure therapy for a Vietnam veteran with PTSD and early-stage dementia. Cognitive and Behavioral Practice, 20(1), 64-73.

26. Fairbank, J. A., Gross, R. T., \& Keane, T. M. (1983). Treatment of posttraumatic stress disorder: Evaluating outcome with a behavioral code. Behavior Modification, 7(4), 557-568.

27. Fairbank, J. A., \& Keane, T. M. (1982). Flooding for combat-related stress disorders: Assessment of anxiety reduction across traumatic memories. Behavior Therapy, 13(4), 499-510.

28. Hytten, K., \& Herlofsen, P. (1989). Accident simulation as a new therapy technique for post-traumatic stress disorder: A case study. Acta Psychiatrica Scandinavica, 80 (355, Suppl.), 79-83.

29. Lyons, J. A., \& Keane, T. M. (Apr 1989). Implosive therapy for the treatment of combat-related PTSD. Journal of Traumatic Stress, 2(2), 137-152.

30. Scurfield, R. M., Wong, L. E., \& Zeerocah, E. B. (1992, February). An evaluation of the impact of "helicopter ride therapy" for in-patient Vietnam veterans with war-related PTSD. Military Medicine, 157(2), 67-73.

31. Yoder, M. S., Tuerk, P. W., \& Acierno, R. (2010). Prolonged exposure with a World War II veteran: 60 years of guilt and feelings of inadequacy. Clinical Case Studies, 9(6), 457-467.

32. Black, J. L., \& Keane, T. M. (1982). Implosive therapy in the treatment of combat related fears in a World War II veteran. Journal of Behavior Therapy and Experimental Psychiatry, 13(2), 163-165.

33. Rauch, S. A. M., Eftekhari, A., \& Ruzek, J. I. (2012). Review of exposure therapy: A gold standard for PTSD treatment. Journal of Rehabilitation Research and Development, 49(5), 679-688.

34. McLay, R. N., Wood, D. P., Webb-Murphy, J. A., Spira, J. L., Wiederhold, M. D., Pyne, J. M., \& Wiederhold, B. K. (2011). A randomized, controlled trial of virtual reality-graded exposure therapy for post-traumatic stress disorder in active duty service members with combat-related post-traumatic stress disorder. Cyberpsychology, Behavior, and Social Networking, 14(4), 223-229.

35. Tworus, R., Szymanska, S., \& Ilnicki, S. (2010). A soldier suffering from PTSD, treated by controlled stress exposition using virtual reality and behavioral training. Cyberpsychology, Behavior, and Social Networking, 13(1), 103-107.

36. Miyahira, S. D., Folen, R. A., Hoffman, H. G., Garcia-Palacios, A., Spira, J. L., \& Kawasaki, M. (2012). The effectiveness of VR exposure therapy for PTSD in returning warfighters. Studies in Health Technology and Informatics, $181,128-132$.
37. Wood, D. P., Wiederhold, B. K., \& Spira, J. (2010). Lessons learned from 350 virtual-reality sessions with warriors diagnosed with combat-related posttraumatic stress disorder. Cyberpsychology, Behavior, and Social Networking, 13(1), 3-11.

38. McLay, R. N., Graap, K., Spira, J., Perlman, K., Johnston, S., Rothbaum, B. O., \& Rizzo, A. (2012). Development and testing of virtual reality exposure therapy for post-traumatic stress disorder in active duty service members who served in iraq and afghanistan. Military Medicine, 177(6), 635-642.

39. McLay, R. N., McBrien, C., Wiederhold, M. D., \& Wiederhold, B. K. (2010). Exposure therapy with and without virtual reality to treat PTSD while in the combat theater: A parallel case series. Cyberpsychology, Behavior and Social Networking, 13(1), 37-42.

40. Ready, D. J., Pollack, S., Rothbaum, B. O., \& Alarcon, R. D. (2006). Virtual reality exposure for veterans with posttraumatic stress disorder. Journal of Aggression, Maltreatment, and Trauma, 12(1-2), 199-220.

41. Reger, G. M., Holloway, K. M., Candy, C., Rothbaum, B. O., Difede, J., Rizzo, A. A., \& Gahm, G. A. (2011). Effectiveness of virtual reality exposure therapy for active duty soldiers in a military mental health clinic. Journal of Traumatic Stress, 24(1), 93-96.

42. Rizzo, A., Difede, J., Rothbaum, B. O., Reger, G., Spitalnick, J., Cukor, J., \& Mclay, R. (2010). Development and early evaluation of the virtual Iraq/Afghanistan exposure therapy system for combat-related PTSD. Annals of the New York Academy of Sciences, 1208(1), 114-125.

43. Rizzo, A., Reger, G., Perlman, K., Rothbaum, B., Difede, J., McLay, R., \& Sharkey, P. M. (2011). Virtual reality posttraumatic stress disorder (PTSD) exposure therapy results with active duty OIF/OEF service members. International Journal on Disability and Human Development, 10(4), 301-308.

44. Rizzo, A., Reger, G., Perlman, K., Rothbaum, B., Difede, J., McLay, R., \& Sharkey, P. M. (2011). Virtual reality posttraumatic stress disorder (PTSD) exposure therapy results with active duty OIF/OEF service members. International Journal on Disability and Human Development, 10(4), 301-308.

45. Rizzo, A. A., Difede, J., Rothbaum, B. O., Johnston, S., McLay, R. N., Reger, G., \& Pair, J. (2009). VR PTSD exposure therapy results with active duty OIF/OEF combatants. Studies in Health Technology and Informatics, 142, 277-282.

46. Rothbaum, B. O., Hodges, L. F., Ready, D., Graap, K., \& Alarcon, R. D. (2001). Virtual reality exposure therapy for Vietnam veterans with posttraumatic stress disorder. Journal of Clinical Psychiatry, 62(8), 617-622.

47. Rothbaum, B. O., Rizzo, A. S., \& Difede, J. (2010). Virtual reality exposure therapy for combat-related posttraumatic stress disorder. Annals of the New York Academy of Sciences, 1208(1), 126-132. 
48. Wood, D. P., Webb-Murphy, J., Mclay, R. N., Wiederhold, B. K., Spira, J. L., Johnston, S., Pyne, J. (2011). Reality graded exposure therapy with physiological monitoring for the treatment of combat related post traumatic stress disorder: A pilot study. Studies in Health Studies and Informatics, 163, 696-702.

49. Wood, D. P., Murphy, J., McLay, R., Koffman, R., Spira, J., Obrecht, R. E., Wiederhold, B. K. (2009). Cost effectiveness of virtual reality graded exposure therapy with physiological monitoring for the treatment of combat related post traumatic stress disorder. Annual Review of CyberTherapy and Telemedicine, 7, 223-229.

50. Ready, D. J., Gerardi, R. J., Backscheider, A. G., Mascaro, N., \& Rothbaum, B. O. (2010). Comparing virtual reality exposure therapy to present-centered therapy with 11 U.S. Vietnam veterans with PTSD. Cyberpsychology, Behavior, and Social Networking, 13(1), 49-54.

51. Roy, M. J., Francis, J., Friedlander, J., Banks-William, L., Lande, R. G., Taylor, P., . . Rothbaum, B. (2008). Initial results from the ViRTICo trial: Virtual reality therapy and imaging in combat veterans. Annual Review of CyberTherapy and Telemedicine, 6, 47-52.

52. Hodges, L. F., Rothbaum, B. O., Alarcon, R., Ready, D., Shahar, F., Graap, K., \& Baltzell, D. (1999). A virtual environment for the treatment of chronic combatrelated post-traumatic stress disorder. CyberPsychology and Behavior, 2(1), 7-14.

53. Rizzo, A. A., Graap, K., Perlman, K., McLay, R. N., Rothbaum, B. O., Reger, G.,. . Pair, J. (2008). Virtual Iraq: Initial results from a VR exposure therapy application for combat-related PTSD. Studies in Health Technology and Informatics, 132, 420-425.

54. Gerardi, M., Rothbaum, B. O., Ressler, K., Heekin, M., \& Rizzo, A. (2008). Virtual reality exposure therapy using a virtual Iraq: Case report. Journal of Traumatic Stress, 21(2), 209-213.

55. Kramer, T. L., Savary, P. E., Pyne, J. M., Kimbrell, T. A., \& Jegley, S. M. (2013). Veteran perceptions of virtual reality to assess and treat posttraumatic stress disorder. Cyberpsychology, Behavior, and Social Networking, 16(4), 293-301.

56. Miyahira, S. D., Folen, R. A., Hoffman, H. G., GarciaPalacios, A., \& Schaper, K. M. (2010). Effectiveness of brief VR treatment for PTSD in warfighters: A case study. Annual Review of CyberTherapy and Telemedicine, 8, 169172.

57. Reger, G. M., Gahm, G. A., Rizzo, A. A., Swanson, R., \& Duma, S. (2009). Soldier evaluation of the virtual reality Iraq. Telemedicine and e-Health, 15(1), 101-104.

58. Rizzo, A., Rothbaum, B. O., \& Graap, K. (2007). Virtual reality applications for the treatment of combatrelated PTSD. In C. R. Figley and W. P. Nash (Eds.), Combat stress injury (pp. 183-204). New York, NY: Routledge/ Taylor \& Francis.
59. Rothbaum, B. O., Ruef, A. M., Litz, B. T., Han, H., \& Hodges, L. (2004). Virtual reality exposure therapy of combat-related PTSD: A case study using psychophysiological indicators of outcome. In S. Taylor (Ed.), Advances in the treatment of posttraumatic stress disorder: Cognitive-behavioral perspectives (pp. 93-112). New York, NY: Springer.

60. Rothbaum, B. O., Hodges, L., Alarcon, R., Ready, D., Shahar, F., Graap, K., \& Baltzell, D. (1999). Virtual reality exposure therapy for PSTD vietnam veterans: A case study. Journal of Traumatic Stress, 12(2), 263-271.

61. Rothbaum, B. O., Ruef, A. M., Litz, B. T., Han, H., \& Hodges, L. (2003). Virtual reality exposure therapy of combat-related PTSD: A case study using psychophysiological indicators of outcome. Journal of Cognitive Psychotherapy: An International Quarterly, 17(2), 163-178.

62. Tworus, R., Szymanska, S., Zbyszewski, M., \& Ilnicki, S. (2010). The man dancing with death: The case of a soldier suffering from PTSD, who was treated by means of the controlled stress exposition method using virtual reality and behavioral training. In B. K. Wiederhold (Ed.), Posttraumatic stress disorder in returning troops (pp. 193201). Amsterdam, the Netherlands: IOS Press.

63. Reger, G. M., \& Gahm, G. A. (2008). Virtual reality exposure therapy for active duty soldiers. Journal of Clinical Psychology, 64(8), 940-946.

64. Spira, J. L., Pyne, J. M., Wiederhold, B., Wiederhold, M., Graap, K., \& Rizzo, A. (2006). Virtual reality and other experiential therapies for combat-related posttraumatic stress disorder. Primary Psychiatry, 13(3), 58-64.

65. Wood, D. P., Murphy, J., Center, K., McLay, R., Reeves, D., Pyne, J., \& Wiederhold, B. K. (2007). Combatrelated post-traumatic stress disorder: A case report using virtual reality exposure therapy with physiological monitoring. Cyberpsychology and Behavior, 10(2), 309-315.

66. Wood, D. P., WebbMurphy, J., Center, K., McLay, R., Koffman, R., Johnston, S., \& Wiederhold, B. K. (2009). Combat-related post-traumatic stress disorder: A case report using virtual reality graded exposure therapy with physiological monitoring with a female seabee. Military Medicine, 174(11), 1215-1222.

67. Wood, D. P., Murphy, J. A., Center, K. B., Russ, C., McLay, R. N., Reeves, D., \& Wiederhold, B. K. (2008). Combat related post traumatic stress disorder: A multiple case report using virtual reality graded exposure therapy with physiological monitoring. Studies in Health Technology and Informatics, 132, 556-561.

68. Cook, J. M., Harb, G. C., Gehrman, P. R., Cary, M. S., Gamble, G. M., Forbes, D., \& Ross, R. J. (2010). Imagery rehearsal for posttraumatic nightmares: A randomized controlled trial. Journal of Traumatic Stress, 23(5), 553-563.

69. Ulmer, C. S., Edinger, J. D., \& Calhoun, P. S. (2011). A multi-component cognitive-behavioral intervention for 
sleep disturbance in veterans with PTSD: A pilot study. Journal of Clinical Sleep Medicine, 7(1), 57-68.

70. Forbes, D., Phelps, A., \& McHugh, T. (2001). Treatment of combat-related nightmares using imagery rehearsal: A pilot study. Journal of Traumatic Stress, 14(2), 433-442.

71. Desai, R. A., Harpaz-Rotem, I., Najavits, L. M., \& Rosenheck, R. A. (2008). Impact of the seeking safety program on clinical outcomes among homeless female veterans with psychiatric disorders. Psychiatric Services, 59(9), 996-1003.

72. Lu, M., Wagner, A., Van Male, L., Whitehead, A., \& Boehnlein, J. (2009). Imagery rehearsal therapy for posttraumatic nightmares in U.S. veterans. Journal of Traumatic Stress, 22(3), 236-239.

73. Nappi, C. M., Drummond, S., Thorp, S. R., \& McQuaid, J. R. (2009). Effectiveness of imagery rehearsal therapy for the treatment of combat-related nightmares in veterans. Sleep, 32, A361.

74. Moore, B. A., \& Krakow, B. (2007). Imagery rehearsal therapy for acute posttraumatic nightmares among combat soldiers in Iraq. American Journal of Psychiatry, 164(4), 683-684.

75. Berlin, K. L., Means, M. K., \& Edinger, J. D. (2010). Nightmare reduction in a Vietnam veteran using imagery rehearsal therapy. Journal of Clinical Sleep Medicine, 6(5), 487-488.

76. Harb, G. C., Cook, J. M., Gehrman, P. R., Gamble, G. M., \& Ross, R. J. (2009). Post-traumatic stress disorder nightmares and sleep disturbance in Iraq war veterans: A feasible and promising treatment combination. Journal of Aggression, Maltreatment, and Trauma, 18(5), 516-531.

77. Moore, B. A., \& Krakow, B. (2010). Imagery rehearsal therapy: An emerging treatment for posttraumatic nightmares in veterans. Psychological Trauma: Theory, Research, Practice, and Policy, 2(3), 232-238.

78. Forbes, D., Lloyd, D., Nixon, R. D. V., Elliott, P., Varker, T., Perry, D., \& Creamer, M. (2012). A multisite randomized controlled effectiveness trial of cognitive processing therapy for military-related posttraumatic stress disorder. Journal of Anxiety Disorders, 26(3), 442-452.

79. Macdonald, A., Monson, C. M., Doron-Lamarca, S., Resick, P. A., \& Palfai, T. P. (2011). Identifying patterns of symptom change during a randomized controlled trial of cognitive processing therapy for military-related posttraumatic stress disorder. Journal of Traumatic Stress, 24(3), 268-276.

80. Suris, A., LinkMalcolm, J., Chard, K., Ahn, C., \& North, C. (2013). A randomized clinical trial of cognitive processing therapy for veterans with PTSD related to military sexual trauma. Journal of Traumatic Stress, 26(1), $28-37$.

81. Monson, C. M., Macdonald, A., Vorstenbosch, V., Shnaider, P., Goldstein, E. S. R., Ferrier-Auerbach, A. G., \& Mocciola, K. E. (2012). Changes in social adjustment with cognitive processing therapy: Effects of treatment and association with PTSD symptom change. Journal of Traumatic Stress, 25(5), 519-526.

82. Monson, C. M., Schnurr, P. P., Resick, P. A., Friedman, M. J., Young-Xu, Y., \& Stevens, S. P. (2006). Cognitive processing therapy for veterans with military-related posttraumatic stress disorder. Journal of Consulting and Clinical Psychology, 74(5), 898-907.

83. Davis, J. J., Walter, K. H., Chard, K. M., Parkinson, R. B., \& Houston, W. S. (2013). Treatment adherence in cognitive processing therapy for combat-related PTSD with history of mild TBI. Rehabilitation Psychology, 58(1), $36-42$.

84. Otis, J. D., Keane, T. M., Kerns, R. D., Monson, C., $\&$ Scioli, E. (2009). The development of an integrated treatment for veterans with comorbid chronic pain and posttraumatic stress disorder. Pain Medicine (Malden, Mass.), 10 (7), 1300-1311.

85. Chard, K. M., Schumm, J. A., McIlvain, S. M., Bailey, G. W., \& Parkinson, R. B. (2011). Exploring the efficacy of a residential treatment program incorporating cognitive processing therapy-cognitive for veterans with PTSD and traumatic brain injury. Journal of Traumatic Stress, 24(3), 347-351.

86. Zappert, L. N., \& Westrup, D. (2008). Cognitive processing therapy for posttraumatic stress disorder in a residential treatment setting. Psychotherapy, 45(3), 361-376.

87. Kearney, D. J., Mcdermott, K., Malte, C., Martinez, M., \& Simpson, T. L. (2013). Effects of participation in a mindfulness program for veterans with posttraumatic stress disorder: A randomized controlled pilot study. Journal of Clinical Psychology, 69(1), 14-27.

88. Boden, M. T., Bernstein, A., Walser, R. D., Bui, L., Alvarez, J., \& Bonn-Miller, M. O. (2012). Changes in facets of mindfulness and posttraumatic stress disorder treatment outcome. Psychiatry Research, 200(2-3), 609-613.

89. Kearney, D. J., McDermott, K., Malte, C., Martinez, M., \& Simpson, T. L. (2012). Association of participation in a mindfulness program with measures of PTSD, depression, and quality of life in a veteran sample. Journal of Clinical Psychology, 68(1), 101-116.

90. Owens, G. P., Walter, K. H., Chard, K. M., \& Davis, P. A. (Mar 2012). Changes in mindfulness skills and treatment response among veterans in residential PTSD treatment. Psychological Trauma: Theory, Research, Practice, and Policy, 4(2), 221-228.

91. Jakupcak, M., Roberts, L. J., Martell, C., Mulick, P., Michael, S., Reed, R., \& McFall, M. (2006). A pilot study of behavioral activation for veterans with posttraumatic stress disorder. Journal of Traumatic Stress, 19(3), 387-391.

92. Jakupcak, M., Wagner, A., Paulson, A., Varra, A., \& McFall, M. (2010). Behavioral activation as a primary carebased treatment for PTSD and depression among returning veterans. Journal of Traumatic Stress, 23(4), 491-495. 
93. Turner, A. P., \& Jakupcak, M. (2010). Behavioral activation for treatment of PTSD and depression in an Iraqi combat veteran with multiple physical injuries. Behavioural and Cognitive Psychotherapy, 38(3), 355-361.

94. Carlson, J. G., Chemtob, C. M., Rusnak, K., Hedlund, N. L., \& Muraoka, M. Y. (1998). Eye movement desensitization and reprocessing (EDMR) treatment for combat-related posttraumatic stress disorder. Journal of Traumatic Stress, 11(1), 3-24.

95. Macklin, M. L., Metzger, L. J., Lasko, N. B., Berry, N. J., Orr, S. P., \& Pitman, R. K. (2000). Five-year followup study of eye movement desensitization and reprocessing therapy for combat-related posttraumatic stress disorder. Comprehensive Psychiatry, 41(1), 24-27.

96. Zimmermann, P., Biesold, K. H., Barre, K., \& Lanczik, M. (2007). Long-term course of post-traumatic stress disorder (PTSD) in German soldiers: Effects of inpatient eye movement desensitization and reprocessing therapy and specific trauma characteristics in patients with noncombat-related PTSD. Military Medicine, 172(5), 456-460.

97. Rogers, S., Silver, S. M., Goss, J., Obenchain, J., Willis, A., \& Whitney, R. L. (1999). A single session, group study of exposure and eye movement desensitization and reprocessing in treating posttraumatic stress disorder among Vietnam war veterans: Preliminary data. Journal of Anxiety Disorders, 13(1-2), 119-130.

98. Silver, S. M., Brooks, A., \& Obenchain, J. (1995). Treatment of vietnam war veterans with PTSD: A comparison of eye movement desensitization and reprocessing, biofeedback, and relaxation training. Journal of Traumatic Stress, 8(2), 337-342.

99. Pitman, R. K., Orr, S. P., Altman, B., Longpre, R. E., Poire, R. E., \& Macklin, M. L. (1996). Emotional processing during eye movement desensitization and reprocessing therapy of Vietnam veterans with chronic posttraumatic stress disorder. Comprehensive Psychiatry, 37(6), 419-429.

100. Carlson, J. G. (1996). Behavioral interventions for posttraumatic stress disorder. In C. D. Spielberger and I. G. Sarason (Eds.), Stress and emotion: Anxiety, anger, and curiosity (pp. 269-303). Washington, DC: Taylor \& Francis.

101. Waters, L. (Spr 1997). Eye movement desensitization and reprocessing treatment for combat PTSD: Commentary. Psychotherapy: Theory, Research, Practice, Training, 34(1), 99.

102. Lipke, H. J., \& Botkin, A. L. (1992). Case studies of eye movement desensitization and reprocessing (EMDR) with chronic post-traumatic stress disorder. Psychotherapy, 29(4), 591-595.

103. Silver, S. M., Rogers, S., \& Russell, M. (2008). Eye movement desensitization and reprocessing (EMDR) in the treatment of war veterans. Journal of Clinical Psychology, 64(8), 947-957.

104. Carlson, J. G., \& Chemtob, C. M. (1997). The role of "resolute perception" in EMDR: Reply to Linda Waters.
Psychotherapy: Theory, Research, Practice, Training, 34 (1), 100.

105. Russell, M. C. (2008). War-related medically unexplained symptoms, prevalence, and treatment: Utilizing EMDR within the armed services. Journal of EMDR Practice and Research, 2(3), 212-225.

106. Thomas, R., \& Gafner, G. (1993). PTSD in an elderly male: Treatment with eye movement desensitization and reprocessing (EMDR). Clinical Gerontologist: Journal of Aging and Mental Health, 14(2), 57-59.

107. Wesson, M., \& Gould, M. (2009). Intervening early with EMDR on military operations. Journal of EMDR Practice and Research, 3(2), 91-97.

108. Wright, S. A., \& Russell, M. C. (2013). Treating violent impulses: A case study utilizing eye movement desensitization and reprocessing with a military client. Clinical Case Studies, 12(2), 128-144.

109. Young, W. C. (1995). Eye movement desensitization/reprocessing: Its use in resolving the trauma caused by the loss of a war buddy. American Journal of Psychotherapy, 49(2), 282-291.

110. Russell, M. C. (2008). War-related medically unexplained symptoms, prevalence, and treatment: Utilizing EMDR within the armed services. Journal of EMDR Practice and Research, 2(3), 212-225.

111. Boden, M. T., Kimerling, R., Jacobs-Lentz, J., Bowman, D., Weaver, C., Carney, D.,... Trafton, J. A. (2012). Seeking safety treatment for male veterans with a substance use disorder and post-traumatic stress disorder symptomatology. Addiction (Abingdon, England), 107(3), 578-586.

112. Alvarez, J., McLean, C., Harris, A. H. S., Rosen, C. S., Ruzek, J. I., \& Kimerling, R. (2011). The comparative effectiveness of cognitive processing therapy for male veterans treated in a VHA posttraumatic stress disorder residential rehabilitation program. Journal of Consulting and Clinical Psychology, 79(5), 590-599.

113. Norman, S. B., Wilkins, K. C., Tapert, S. F., Lang, A. J., \& Najavits, L. M. (2010). A pilot study of seeking safety therapy with OEF/OIF veterans. Journal of Psychoactive Drugs, 42(1), 83-87.

114. Long, M. E., Hammons, M. E., Davis, J. L., Frueh, B. C., Khan, M. M., Elhai, J. D., \& Teng, E. J. (2011). Imagery rescripting and exposure group treatment of posttraumatic nightmares in veterans with PTSD. Journal of Anxiety Disorders, 25(4), 531-535.

115. Cook, J. M., Walser, R. D., Kane, V., Ruzek, J. I., \& Woody, G. (2006). Dissemination and feasibility of a cognitive-behavioral treatment for substance use disorders and posttraumatic stress disorder in the veterans administration. Journal of Psychoactive Drugs, 38(1), 89-92.

116. Desai, R. A., Harpaz-Rotem, I., Najavits, L. M., \& Rosenheck, R. A. (2008). Impact of the seeking safety program on clinical outcomes among homeless female 
veterans with psychiatric disorders. Psychiatric Services (Washington, DC), 59(9), 996-1003.

117. Ready, D. J., Thomas, K. R., Worley, V., Backscheider, A. G., Harvey, L. A., Baltzell, D., \& Rothbaum, B. O. (2008). A field test of group based exposure therapy with 102 veterans with war-related posttraumatic stress disorder. Journal of Traumatic Stress, 21(2), 150-157.

118. Sutherland, R. J., Mott, J. M., Lanier, S. H., Williams, W., Ready, D. J., \& Teng, E. J. (2012). A pilot study of a 12-week model of group-based exposure therapy for veterans with PTSD. Journal of Traumatic Stress, 25 (2), 150-156.

119. Swanson, L. M., Favorite, T. K., Horin, E., \& Arnedt, J. T. (2009). A combined group treatment for nightmares and insomnia in combat veterans: A pilot study. Journal of Traumatic Stress, 22(6), 639-642.

120. Mott, J. M., Sutherland, R. J., Williams, W., Lanier, S. H., Ready, D. J., \& Teng, E. J. (2013). Patient perspectives on the effectiveness and tolerability of groupbased exposure therapy for posttraumatic stress disorder: Preliminary self-report findings from 20 veterans. Psychological Trauma: Theory, Research, Practice, and Policy, 5 (5), 453-461.

121. Bolton, E. E., Lambert, J. F., Wolf, E. J., Raja, S., Varra, A. A., \& Fisher, L. M. (2004). Evaluating a cognitive-behavioral group treatment program for veterans with posttraumatic stress disorder. Psychological Services, 1(2), $140-146$.

122. Castillo, D. T., C'de Baca, J., Qualls, C., \& Bornovalova, M. A. (2012). Group exposure therapy treatment for post-traumatic stress disorder in female veterans. Military Medicine, 177(12), 1486-1491.

123. Kibler, J. L., \& Lyons, J. A. (2008). Brief cognition-focused group therapy for depressive symptoms in chronic posttraumatic stress disorder: A pilot study. Journal of Psychological Trauma, 7(2), 122-138.

124. Rademaker, A. R., Vermetten, E., \& Kleber, R. J. (Oct 2009). Multimodal exposure-based group treatment for peacekeepers with PTSD: A preliminary evaluation. Military Psychology, 21(4), 482-496.

125. Ready, D. J., Sylvers, P., Worley, V., Butt, J., Mascaro, N., \& Bradley, B. (2012). The impact of groupbased exposure therapy on the PTSD and depression of 30 combat veterans. Psychological Trauma: Theory, Research, Practice, and Policy, 4(1), 84-93.

126. Ready, D. J., Vega, E. M., Worley, V., \& Bradley, B. (2012). Combining group-based exposure therapy with prolonged exposure to treat U.S. Vietnam veterans with PTSD: A case study. Journal of Traumatic Stress, 25(5), 574-577.

127. Donovan, B., Padin-Rivera, E., \& Kowaliw, S. (2001). "Transcend": Initial outcomes from a posttraumatic stress disorder/substance abuse treatment program. Journal of Traumatic Stress, 14(4), 757-772.
128. Khoo, A., Dent, M. T., \& Oei, T. P. S. (2011). Group cognitive behaviour therapy for military servicerelated post-traumatic stress disorder: Effectiveness, sustainability, and repeatability. Australian and New Zealand Journal of Psychiatry, 45(8), 663-672.

129. Ford, J. D., \& Stewart, J. (1999). Group psychotherapy for war-related PTSD with military veterans. In B. H. Young \& D. D. Blake (Eds.), Group treatments for posttraumatic stress disorder (pp. 75-100). Philadelphia, PA: Brunner/Mazel.

130. Foy, D. W., Ruzek, J. I., Glynn, S. M., Riney, S. J., \& Gusman, F. D. (1997). Trauma focus group therapy for combat-related PTSD. In Session: Psychotherapy in Practice, 3(4), 59-73.

131. Foy, D. W., Ruzek, J. I., Glynn, S. M., Riney, S. J., $\&$ Gusman, F. D. (2002). Trauma focus group therapy for combat-related PTSD: An update. Journal of Clinical Psychology, 58(8), 907-918.

132. Litz, B. T., Engel, C. C., Bryant, R. A., \& Papa, A. (2007). A randomized, controlled proof-of-concept trial of an internet-based, therapist-assisted self-management treatment for posttraumatic stress disorder. American Journal of Psychiatry, 164(11), 1676-1683.

133. Gros, D. F., Yoder, M., Tuerk, P. W., Lozano, B. E., \& Acierno, R. (2011). Exposure therapy for PTSD delivered to veterans via telehealth: Predictors of treatment completion and outcome and comparison to treatment delivered in person. Behavior Therapy, 42(2), 276-283.

134. Lanche, M., Perkins, C. J., \& Stoltzfoos, L. (Feb 2008). Live, online CBT helps service members with PTSD. Primary Psychiatry, 15(2), 20.

135. Strachan, M., Gros, D. F., Ruggiero, K. J., Lejuez, C. W., \& Acierno, R. (2012). An integrated approach to delivering exposure-based treatment for symptoms of PTSD and depression in OIF/OEF veterans: Preliminary findings. Behavior Therapy, 43(3), 560-569.

136. Tuerk, P. W., Yoder, M., Ruggiero, K. J., Gros, D. F., \& Acierno, R. (2010). A pilot study of prolonged exposure therapy for posttraumatic stress disorder delivered via telehealth technology. Journal of Traumatic Stress, 23(1), 116-123.

137. Tuerk, P. W., Yoder, M., Ruggiero, K. J., Gros, D. F., \& Acierno, R. (2010). A pilot study of prolonged exposure therapy for posttraumatic stress disorder delivered via telehealth technology. Journal of Traumatic Stress, 23(1), 116-123.

138. Carmody, T., Goldman, A., Reyes, N., Mozgai, S., Huggins, J., Solkowitz, S., \& Lee, S. (2010). Telephonedelivered cognitive behavior therapy for chronic pain: Participant characteristics. Journal of Pain, 11(4 Suppl. 1), S56.

139. Morland, L. A., Greene, C. J., Rosen, C. S., Foy, D., Reilly, P., Shore, J., ... Frueh, B. C. (2010). Telemedicine for anger management therapy in a rural population of combat veterans with posttraumatic stress disorder: A 
randomized non inferiority trial. Journal of Clinical Psychiatry, 71(7), 85-863.

140. Morland, L. A., Hynes, A. K., Mackintosh, M., Resick, P. A., \& Chard, K. M. (2011). Group cognitive processing therapy delivered to veterans via telehealth: A pilot cohort. Journal of Traumatic Stress, 24(4), 465-469.

141. Van Voorhees, B. W., Gollan, J., \& Fogel, J. (2012). Pilot study of internet-based early intervention for combat-related mental distress. Journal of Rehabilitation Research and Development, 49(8), 1175-1190.

142. Strachan, M., Gros, D. F., Ruggiero, K. J., Lejuez, C. W., \& Acierno, R. (2012). An integrated approach to delivering exposure-based treatment for symptoms of PTSD and depression in OIF/OEF veterans: Preliminary findings. Behavior Therapy, 43(3), 560-569.

143. Bishop, T. M., Possemato, K., Acosta, M., Lantinga, L. J., Maisto, S. A., Marsch, L., \& Rosenblum, A. (2012). Moving forward: Update on the development of a web-based cognitive behavioral treatment for OEF/OIF veterans with PTSD symptoms and substance misuse. Alcoholism: Clinical and Experimental Research, 36, 347A.

144. Frueh, B. C., de Arellano, M. A., \& Turner, S. M. (1997). Systematic desensitization as an alternative exposure strategy for PTSD. American Journal of Psychiatry, 154(2), 287-288.

145. Glynn, S. M., Eth, S., Randolph, E. T., Foy, D. W., Leong, G. B., Paz, G. G., \& Katzman, J. W. (1995). Behavioral family therapy for Vietnam combat veterans with posttraumatic stress disorder. Journal of Psychotherapy Practice and Research, 4(3), 214-223.

146. Gros, D. F., Price, M., Strachan, M., Yuen, E. K., Milanak, M. E., \& Acierno, R. (2012). Behavioral activation and therapeutic exposure: An investigation of relative symptom changes in PTSD and depression during the course of integrated behavioral activation, situational exposure, and imaginal exposure techniques. Behavior Modification, 36(4), 580-599.

147. Monson, C. M., Fredman, S. J., Macdonald, A., Pukay-Martin, N. D., Resick, P. A., \& Schnurr, P. P. (2012). Effect of cognitive-behavioral couple therapy for PTSD: A randomized controlled trial. JAMA, 308(7), 700-709.

148. Monson, C. M., Schnurr, P. P., Stevens, S. P., \& Guthrie, K. A. (2004). Cognitive-behavioral couple's treatment for posttraumatic stress disorder: Initial findings. Journal of Traumatic Stress, 17(4), 341-344.

149. Rotunda, R. J., O'Farrell, T. J., Murphy, M., \& Babey, S. H. (2008). Behavioral couples therapy for comorbid substance use disorders and combat-related posttraumatic stress disorder among male veterans: An initial evaluation. Addictive Behaviors, 33(1), 180-187.

150. Spoont, M. R., Sayer, N. A., Thuras, P., Erbes, C., \& Winston, E. (2003). Practical psychotherapy: Adaptation of dialectical behavior therapy by a VA medical center. Psychiatric Services (Washington, DC), 54(5), 627-629.
151. Boden, M. T., Bonn-Miller, M. O., Kashdan, T. B., Alvarez, J., \& Gross, J. J. (2012). The interactive effects of emotional clarity and cognitive reappraisal in posttraumatic stress disorder. Journal of Anxiety Disorders, 26(1), 233-238.

152. Cahill, S. P., Rauch, S. A., Hembree, E. A., \& Foa, E. B. (2004). Effect of cognitive-behavioral treatments for PTSD on anger. In S. Taylor (Ed.), Advances in the treatment of posttraumatic stress disorder: Cognitive-behavioral perspectives (pp. 175-196). New York, NY: Springer.

153. Garcia, C. B. (2005). Cognitive-behavioral intervention for PTSD in Colombian combat veterans [Efectividad de una intervencion cognitivo-conductual para el trastorno por estres postraumatico en excombatientes Colombianos]. Universitas Psychologica, 4(2), 205-219.

154. Chemtob, C. M., Hamada, R. S., Novaco, R. W., \& Gross, D. M. (1997). Cognitive-behavioral treatment for severe anger in posttraumatic stress disorder. Journal of Consulting and Clinical Psychology, 65(1), 184-189.

155. Ochsner Margolies, S. (2012). Efficacy of a cognitive-behavioral treatment for insomnia among Afghanistan and Iraq (OEF/OIF) veterans with PTSD. Dissertation Abstracts International: Section B: The Sciences and Engineering, 73(4-B), 2513.

156. Gellis, L. A., \& Gehrman, P. R. (2011). Cognitive behavioral treatment for insomnia in veterans with longstanding posttraumatic stress disorder: A pilot study. Journal of Aggression, Maltreatment, and Trauma, 20(8), 904-916.

157. Pigeon, W. R., Matteson-Rusby, S. E., Claassen, C., \& Knox, K. (2010). CBT for sleep disturbances in combat veterans: Preliminary findings. Sleep, 33, A236.

158. Jeffreys, M. D., Reinfeld, C., Nair, P. V., Garcia, H. A., Mata-Galan, E., \& Rentz, T. O. (2014). Evaluating treatment of posttraumatic stress disorder with cognitive processing therapy and prolonged exposure therapy in a VHA specialty clinic. Journal of Anxiety Disorders, 28(1), 108-114.

159. Katz, L. S., Snetter, M. R., Robinson, A. H., Hewitt, P., \& Cojucar, G. (2008). Holographic reprocessing: Empirical evidence to reduce posttraumatic cognitions in women veterans with PTSD from sexual trauma and abuse. Psychotherapy, 45(2), 186-198.

160. Blevins, D., Roca, J. V., \& Spencer, T. (2011). Life guard: Evaluation of an ACT-based workshop to facilitate reintegration of OIF/OEF veterans. Professional Psychology: Research and Practice, 42(1), 32-39.

161. Orsillo, S. M., \& Batten, S. V. (2005). Acceptance and commitment therapy in the treatment of posttraumatic stress disorder. Behavior Modification, 29(1), 95-129.

162. Zinati Afkham, A., \& Sahragard Toghchi, M. (2012). The effectiveness of imagery rescripting and reprocessing therapy on reduction of subjective units of distress and recurrent images on war disabled with PTSD. European Psychiatry, 27(Suppl. 1). 
163. Cockram, D. M., Drummond, P. D., \& Lee, C. W. (2010). Role and treatment of early maladaptive schemas in Vietnam veterans with PTSD. Clinical Psychology and Psychotherapy, 17(3), 165-182.

164. Frueh, B. C., Turner, S. M., Beidel, D. C., Mirabella, R. F., \& Jones, W. J. (1996). Trauma management therapy: A preliminary evaluation of a multicomponent behavioral treatment for chronic combat-related PTSD. Behaviour Research and Therapy, 34(7), 533-543.

165. Turner, S. M., Beidel, D. C., \& Frueh, B. C. (2005). Multicomponent behavioral treatment for chronic combat-related posttraumatic stress disorder: Trauma management therapy. Behavior Modification, 29(1), 39-69.

166. Wald, J., \& Taylor, S. (2010). Implementation and outcome of combining interoceptive exposure with traumarelated exposure therapy in a patient with combat-related posttraumatic stress disorder. Clinical Case Studies, 9(4), 243-259.

167. Gray, M. J., Schorr, Y., Nash, W., Lebowitz, L., Amidon, A., Lansing, A., .. Litz, B. T. (2012). Adaptive disclosure: An open trial of a novel exposure-based intervention for service members with combat-related psychological stress injuries. Behavior Therapy, 43(2), 407-415.

168. Haynes, P., Kelly, M., Scheller, V., Quan, S. F., \& Bootzin, R. R. (2009). Stabilizing sleep and daily routine in veterans with comorbid PTSD and depression: Follow-up outcomes for cognitive behavioral social rhythm therapy. Sleep, 32, A344.

169. Schnurr, P. P., Friedman, M. J., Foy, D. W., Shea, M. T., Hsieh, F. Y., Lavori, P. W., \& Bernardy, N. C. (2003). Randomized trial of trauma-focused group therapy for posttraumatic stress disorder: Results from a department of veterans affairs cooperative study. Archives of General Psychiatry, 60(5), 481-489.

170. Harris, J. I., Erbes, C. R., Engdahl, B. E., Thuras, P., Murray-Swank, N., Grace, D., ... Le, T. (2011). The effectiveness of a trauma focused spiritually integrated intervention for veterans exposed to trauma. Journal of Clinical Psychology, 67(4), 425-438.

171. Bertovic, G., Varenina, G., Franciskovic, T., \& Moro, L. (1992). Evaluation of short-term group psychotherapeutic treatment of soldiers suffering from psychical traumas. Psychologische Beitrage [Psychological Contributions], 34(3-4), 280-288.

172. Bormann, J. E., Thorp, S., Wetherell, J. L., \& Golshan, S. (2008). A spiritually based group intervention for combat veterans with posttraumatic stress disorder: Feasibility study. Journal of Holistic Nursing: Official Journal of the American Holistic Nurses' Association, 26(2), 109-116.

173. Ray, R. D., \& Webster, R. (2010). Group interpersonal psychotherapy for veterans with posttraumatic stress disorder: A pilot study. International Journal of Group Psychotherapy, 60(1), 131-140.
174. Cook, J. M., O’Donnell, C., Moltzen, J. O., Ruzek, J. I., \& Sheikh, J. I. (2005). Clinical observations in the treatment of World War II and Korean War veterans with combat-related PTSD. Clinical Gerontologist, 29(2), 81-93.

175. Ruzek, J. I., Riney, S. J., Leskin, G., Drescher, K. D., Foy, D. W., \& Gusman, F. D. (2001). Do posttraumatic stress disorder symptoms worsen during trauma focus group treatment? Military Medicine, 166 (10), 898-902.

176. Britvic, D., Anticevic, V., Urlic, I., Dodig, G., Lapenda, B., Kekez, V., \& Mustapicc, I. (2007). Psychotherapeutic treatment program for post-traumatic stress disorder: Prospective study of 70 war veterans. Group Analysis, 40(4), 507-522.

177. Britvic, D., Radelic, N., \& Urlic, I. (2006). Longterm dynamic-oriented group psychotherapy of posttraumatic stress disorder in war veterans: Prospective study of five-year treatment. Croatian Medical Journal, 47(1), 76-84.

178. Busuttil, W., Turnbull, G. J., Neal, L. A., Rollins, J., West, A. G., Blanch, N., \& Herepath, R. (1995). Incorporating psychological debriefing techniques within a brief group psychotherapy programme for the treatment of posttraumatic stress disorder. British Journal of Psychiatry, 167 (4), 495-502.

179. Britvic, D., Glucina, D., Anticevic, V., Kekez, V., Lapenda, B., Dogas, V., \& Ciskovic, T. F. (2012). Longterm improvement in coping skills following multimodal treatment in war veterans with chronic PTSD. International Journal of Group Psychotherapy, 62(3), 418-435.

180. Boehnlein, J. K., \& Sparr, L. F. (1993). Group therapy with WWII ex-POWs: Long-term posttraumatic adjustment in a geriatric population. American Journal of Psychotherapy, 47(2), 273-282.

181. Bonwick, R. (1998). Group treatment programme for elderly war veterans with PTSD. International Journal of Geriatric Psychiatry, 13(1), 64-65.

182. Evans, M., \& Marad, G. (1993). A triage model of psychotherapeutic group intervention. Archives of Psychiatric Nursing, 7(4), 244-248.

183. Kanas, N., Schoenfeld, F., Marmar, C. R., Weiss, D. S., \& Koller, P. (Sum 1994). Process and content in a long-term PTSD therapy group for Vietnam veterans. Group, 18(2), 78-88.

184. LeLieuvre, R. B. (Feb 1998). "Goodnight saigon”: Music, fiction, poetry, and film in readjustment group counseling. Professional Psychology: Research and Practice, 29(1), 74-78.

185. Makler, S., Sigal, M., Gelkopf, M., Bar Kochba, B., \& Horeb, E. (1990). Combat-related, chronic posttraumatic stress disorder: Implications for group-therapy intervention. American Journal of Psychotherapy, 44(3), 381-395. 
186. Urlic, I. (1999). Aftermath of war experience: Impact of anxiety and aggressive feelings on the group and the therapist. Croatian Medical Journal, 40(4), 486-492.

187. Brockway, S. S. (1987). Group treatment of combat nightmares in post-traumatic stress disorder. Journal of Contemporary Psychotherapy, 17(4), 270-284.

188. Catherall, D. R. (1986). The support system and amelioration of PTSD in Vietnam veterans. Psychotherapy: Theory, Research, Practice, Training, 23(3), 472-482.

189. Catherall, D. R., \& Lane, C. (1992). Warrior therapist: Vets treating vets. Journal of Traumatic Stress, 5(1), 19-36.

190. Ford, J. D., \& Stewart, J. (1999). Group psychotherapy for war-related PTSD with military veterans. In B. H. Young \& D. D. Blake (Eds.), Group treatments for posttraumatic stress disorder (pp. 75-100). Philadelphia, PA: Brunner/Mazel.

191. Ford, J. D., \& Stewart, J. (1999). Group psychotherapy for war-related PTSD with military veterans. In B. H. Young \& D. D. Blake (Eds.), Group treatments for posttraumatic stress disorder (pp. 75-100). Philadelphia, PA: Brunner/Mazel.

192. Galloucis, M., \& Kaufman, M. E. (1988). Group therapy with Vietnam veterans: A brief review. Group, 12 (2), 85-102.

193. Jain, S., McLean, C., \& Rosen, C. S. (2012). Is there a role for peer support delivered interventions in the treatment of veterans with post-traumatic stress disorder? Military Medicine, 177(5), 481-483.

194. Rozynko, V., \& Dondershine, H. E. (1991). Trauma focus group therapy for Vietnam veterans with PTSD. Psychotherapy, 28(1), 157-161.

195. Jones, L., Brazel, D., Peskind, E. R., Morelli, T., \& Raskind, M. A. (2000). Group therapy program for African-American veterans with posttraumatic stress disorder. Psychiatric Services, 51(9), 1177-1179.

196. Kingsley, G. (2007). Contemporary group treatment of combat-related posttraumatic stress disorder. Journal of the American Academy of Psychoanalysis and Dynamic Psychiatry, 35(1), 51-69.

197. Murphy, R. T., Rosen, C. S., Cameron, R. P., \& Thompson, K. E. (2002). Development of a group treatment for enhancing motivation to change PTSD symptoms. Cognitive and Behavioral Practice, 9(4), 308-316.

198. Sloan, D. M., Bovin, M. J., \& Schnurr, P. P. (2012). Review of group treatment for PTSD. Journal of Rehabilitation Research and Development, 49(5), 689-702.

199. Frueh, B. C., Monnier, J., Yim, E., Grubaugh, A. L., Hamner, M. B., \& Knapp, R. G. (2007). A randomized trial of telepsychiatry for post-traumatic stress disorder. Journal of Telemedicine and Telecare, 13(3), 142-147.

200. Rosen, C. S., Tiet, Q. Q., Harris, A. H., Julian, T. F., McKay, J. R., Moore, W. M., ... Schnurr, P. P. (2013). Telephone monitoring and support after discharge from residential PTSD treatment: A randomized controlled trial. Psychiatric Services (Washington, DC), 64(1), 13-20.

201. Sloan, D. M., Gallagher, M. W., Feinstein, B. A., Lee, D. J., \& Pruneau, G. M. (2011). Efficacy of telehealth treatments for posttraumatic stress-related symptoms: A meta-analysis. Cognitive Behaviour Therapy, 40(2), $111-125$.

202. Greene, C. J., Morland, L. A., MacDonald, A., Frueh, B. C., Grubbs, K. M., \& Rosen, C. S. (2010). How does tele-mental health affect group therapy process? Secondary analysis of a noninferiority trial. Journal of Consulting and Clinical Psychology, 78(5), 746-750.

203. Niles, B. L., KlunkGillis, J., Ryngala, D. J., Silberbogen, A. K., Paysnick, A., \& Wolf, E. J. (2012). Comparing mindfulness and psychoeducation treatments for combat-related PTSD using a telehealth approach. Psychological Trauma: Theory, Research, Practice, and Policy, 4 (5), 538-547.

204. Niles, B., Seligowski, A., \& Silberbogen, A. (2012). Measuring mindfulness: Which aspects of mindfulness change following a brief telehealth intervention for PTSD? BMC Complementary and Alternative Medicine, 12 (Suppl. 1), 191.

205. Morland, L. A., Pierce, K., \& Wong, M. Y. (2004). Telemedicine and coping skills groups for Pacific Island veterans with post-traumatic stress disorder: A pilot study. Journal of Telemedicine and Telecare, 10(5), 286-289.

206. Possemato, K., Ouimette, P., \& Knowlton, P. (2011). A brief self-guided telehealth intervention for posttraumatic stress disorder in combat veterans: A pilot study. Journal of Telemedicine and Telecare, 17(5), 245-250.

207. Mozer, E., Franklin, B., \& Rose, J. (2008). Psychotherapeutic intervention by telephone. Clinical Interventions in Aging, 3(2), 391-396.

208. Nieves, J. E., Candelario, J., Short, D., \& Briscoe, G. (2009). Telemental health for our soldiers: A brief review and a new pilot program. Military Medicine, 174 (12), xxi-xxii.

209. Rosen, C. S., DiLandro, C., Corwin, K. N., Drescher, K. D., Cooney, J. H., \& Gusman, F. (2006). Telephone monitoring and support for veterans with chronic posttraumatic stress disorder: A pilot study. Community Mental Health Journal, 42(5), 501-508.

210. Brinkman, W., Vermetten, E., van den Steen, M., $\&$ Neerincx, M. A. (2011). Cognitive engineering of a military multi-modal memory restructuring system. Journal of Cyber Therapy and Rehabilitation, 4(1), 83-99.

211. Olden, M., Cukor, J., Rizzo, A. S., Rothbaum, B., $\&$ Difede, J. (2010). House calls revisited: Leveraging technology to overcome obstacles to veteran psychiatric care and improve treatment outcomes. Annals of the New York Academy of Sciences, 1208(1), 133-141.

212. Jain, S., McMahon, G. F., Hasen, P., Kozub, M. P., Porter, V., King, R., \& Guarneri, E. M. (2012). Healing touch with guided imagery for PTSD in returning active 
duty military: A randomized controlled trial. Military Medicine, 177(9), 1015-1021.

213. Nakamura, Y., Lipschitz, D. L., Landward, R., Kuhn, R., \& West, G. (2011). Two sessions of sleepfocused mind-body bridging improve self-reported symptoms of sleep and PTSD in veterans: A pilot randomized controlled trial. Journal of Psychosomatic Research, 70(4), 335-345.

214. Bremner, J. D., Afzal, N., Vaccarino, V., Carmody, J., \& Divitale, S. (2011). Mindfulness based stress reduction (MBSR) in the treatment of iraq combat-related PTSD. Psychosomatic Medicine, 73(3), A39.

215. Bormann, J. E., Thorp, S. R., Wetherell, J. L., Golshan, S., \& Lang, A. J. (2013). Meditation-based mantram intervention for veterans with posttraumatic stress disorder: A randomized trial. Psychological Trauma: Theory, Research, Practice, and Policy, 5(3), 259-267.

216. Brooks, J. S., \& Scarano, T. (Nov 1985). Transcendental meditation in the treatment of post-vietnam adjustment. Journal of Counseling and Development, 64(3), 212-215.

217. Bormann, J. E., Smith, T. L., Becker, S., Gershwin, M., Pada, L., Grudzinski, A. H., \& Nurmi, E. A. (2005). Efficacy of frequent mantram repetition on stress, quality of life, and spiritual well-being in veterans: A pilot study. Journal of Holistic Nursing, 23(4), 395-414.

218. Stetz, M. C., KaloiChen, J. Y., Turner, D. D., Bouchard, S., Riva, G., \& Wiederhold, B. K. (2011). The effectiveness of technology-enhanced relaxation techniques for military medical warriors. Military Medicine, 176(9), 1065-1070.

219. Stankovic, L. (2011). Transforming trauma: A qualitative feasibility study of integrative restoration (iRest) yoga nidra on combat-related post-traumatic stress disorder. International Journal of Yoga Therapy, (21), 23-37.

220. Hull, A., Reinhard, M., McCoy, K., Akhter, J., Duncan, A., Soltes, K., ... Berndtson, K. (2012). Acupuncture and meditation for military veterans: Patient satisfaction and self reported symptom reduction. $B M C$ Complementary and Alternative Medicine, 12(Suppl. 1).

221. Strauss, J. L., Calhoun, P. S., \& Marx, C. E. (2009). Guided imagery as a therapeutic tool in post-traumatic stress disorder. In P. J. Shiromani, T. M. Keane, \& J. E. LeDoux (Eds.), Post-traumatic stress disorder; Basic science and clinical practice (pp. 363-373). New York, NY: Humana Press.

222. Bensimon, M., Amir, D., \& Wolf, Y. (2012). A pendulum between trauma and life: Group music therapy with post-traumatized soldiers. Arts in Psychotherapy, 39 (4), 223-233.

223. Bensimon, M., Amir, D., \& Wolf, Y. (2008). Drumming through trauma: Music therapy with post-traumatic soldiers. Arts in Psychotherapy, 35(1), 34-48.

224. Morgan, C. A. I., \& Johnson, D. R. (1995). Use of a drawing task in the treatment of nightmares in combat-related post-traumatic stress disorder. Art Therapy, 12(4), 244-247.

225. Nanda, U., Barbato Gaydos, H. L., Hathorn, K., \& Watkins, N. (2010, May). Art and posttraumatic stress: A review of the empirical literature on the therapeutic implications of artwork for war veterans with posttraumatic stress disorder. Environment and Behavior, 42(3), 376-390.

226. Berkowitz, S. (1990). Art therapy with a Vietnam veteran who has post traumatic stress disorder. Pratt Institute Creative Arts Therapy Review, 11, 47-62.

227. Hines-Martin, V. P., \& Ising, M. (1993). Use of art therapy with post-traumatic stress disordered veteran clients. Journal of Psychosocial Nursing and Mental Health Services, 31(9), 29-36.

228. Horgan, J. (1988). Rx: Art. Scientific American, $258(6), 38$.

229. Lande, R. G., Tarpley, V., Francis, J. L., \& Boucher, R. (2010). Combat trauma art therapy scale. Arts in Psychotherapy, 37(1), 42-45.

230. Feinstein, D. (2010). Rapid treatment of PTSD: Why psychological exposure with acupoint tapping may be effective. Psychotherapy: Theory, Research, Practice, Training, 47(3), 385-402.

231. Blackburn, A. B., O'Connell, W. E., \& Richman, B. W. (Sep 1984). Post-traumatic stress disorder, the Vietman veteran, and adlerian natural high therapy. Individual Psychology: Journal of Adlerian Theory, Research, and Practice, 40(3), 317-332.

232. Cornelius, S. K., Kline, C. E., Anderson, J., Ginsberg, J. P., \& Youngstedt, S. D. (2010). The effect of bright light therapy on PTSD related sleep disturbances. Sleep, 33, A237.

233. Ritchie, E. C., \& Amaker, R. J. (2012). Canineassisted therapy in military medicine: The early years. U.S. Army Medical Department Journal, (April-June), 5-7.

234. Rubenstein, D. A., Debboun, M., \& Burton, R. (2012). Canine-assisted therapy in military medicine. perspectives: Commander's introduction. U.S. Army Medical Department Journal, (April-June), 1-4.

235. Yeager, A. F., \& Irwin, J. (2012). Rehabilitative canine interactions at the Walter Reed National Military Medical Center. U.S. Army Medical Department Journal, (April-June), 57-60.

236. Foreman, K., \& Crosson, C. (2012). Canines for combat veterans: The national education for assistance dog services. U.S. Army Medical Department Journal, (AprilJune), 61-62.

237. Yount, R. A., Olmert, M. D., \& Lee, M. R. (2012). Service dog training program for treatment of posttraumatic stress in service members. U.S. Army Medical Department Journal, (April-June), 63-69.

238. Church, D., Hawk, C., Brooks, A. J., Toukolehto, O., Wren, M., Dinter, I., \& Stein, P. (2013). Psychological trauma symptom improvement in veterans using emotional 
freedom techniques: A randomized controlled trial. Journal of Nervous and Mental Disease, 201(2), 153-160.

239. Church, D. (2010). The treatment of combat trauma in veterans using EFT (emotional freedom techniques): A pilot protocol. Traumatology, 16(1), 55-65.

240. Harmand, J., Ashlock, L. E., \& Miller, T. W. (1993). Treating post-traumatic stress disorder among Vietnam combat veterans: An existential perspective. Journal of Contemporary Psychotherapy, 23(4), 281-291.

241. Saldanha, D. (2002). Family intervention in the treatment of post-traumatic stress disorders. Journal of Projective Psychology and Mental Health, 9(1), 57-61.

242. Boland, M. W. (2010). Bringing family together. a family treatment model for combat-related posttraumatic stress disorder. Dissertation Abstracts International: Section B: The Sciences and Engineering, 70(10-B), 6539.

243. Crump, L. D. (1984). Gestalt therapy in the treatment of Vietnam veterans experiencing PTSD symptomatology. Journal of Contemporary Psychotherapy, 14(1), 90-98.

244. Abramowitz, E. G., Barak, Y., Ben-Avi, I., \& Knobler, H. Y. (2008). Hypnotherapy in the treatment of chronic combat-related PTSD patients suffering from insomnia: A randomized, zolpidem-controlled clinical trial. International Journal of Clinical and Experimental Hypnosis, 56(3), 270-280.

245. Abramowitz, E. G., \& Lichtenberg, P. (2010). A new hypnotic technique for treating combat-related posttraumatic stress disorder: A prospective open study. International Journal of Clinical and Experimental Hypnosis, 58(3), 316-328.

246. Cardena, E. (2000). Hypnosis in the treatment of trauma: A promising, but not fully supported, efficacious intervention. International Journal of Clinical and Experimental Hypnosis, 48(2), 225-238.

247. Degun-Mather, M. (2001). The value of hypnosis in the treatment of chronic PTSD with dissociative fugues in a war veteran. Contemporary Hypnosis, 18(1), 4-13.

248. Devilly, G. J. (2002). The psychological effects of a lifestyle management course on war veterans and their spouses. Journal of Clinical Psychology, 58(9), 1119-1134.

249. Gilmartin, R. M., \& Southwick, S. (2004). Combat-related PTSD and logotherapy. International Forum for Logotherapy, 27(1), 34-38.

250. Southwick, S. M., Gilmartin, R., McDonough, P., \& Morrissey, P. (2006). Logotherapy as an adjunctive treatment for chronic combat-related PTSD: A meaning-based intervention. American Journal of Psychotherapy, 60(2), 161-174.

251. Bormann, J. E., Liu, L., Thorp, S. R., \& Lang, A. J. (2012). Spiritual wellbeing mediates PTSD change in veterans with military-related PTSD. International Journal of Behavioral Medicine, 19(4), 496-502.

252. Solomon, P. G. (2006). A mythological studies approach to PTSD among Vietnam combat veterans: From memory through myth to meaning. Dissertation Abstracts International Section A: Humanities and Social Sciences, 67(6-A), 2186.

253. Gelkopf, M., Hasson-Ohayon, I., Bikman, M., \& Kravetz, S. (2013). Nature adventure rehabilitation for combat-related posttraumatic chronic stress disorder: A randomized control trial. Psychiatry Research, 209(3), 485-493.

254. Hyer, L., Boyd, S., Scurfield, R., Smith, D., \& Burke, J. (1996). Effects of outward bound experience as an adjunct to inpatient PTSD treatment of war veterans. Journal of Clinical Psychology, 52(3), 263-278.

255. Otter, L., \& Currie, J. (2004). A long time getting home: Vietnam veterans' experiences in a community exercise rehabilitation programme. Disability and Rehabilitation, 26(1), 27-34.

256. Grigsby, J. P. (1987). The use of imagery in the treatment of posttraumatic stress disorder. Journal of Nervous and Mental Disease, 175(1), 55-59.

257. Kudler, H. (2007). The need for psychodynamic principles in outreach to new combat veterans and their families. Journal of the American Academy of Psychoanalysis and Dynamic Psychiatry, 35(1), 39-50.

258. Kudler, H. (2011). Psychodynamic psychotherapy. In E. B. Foa, T. M. Keane, M. J. Friedman, \& J. A. Cohen (Eds.), Effective treatments for PTSD (2nd ed., pp. 107124). Guilford Press.

259. Schnurr, P. P., Shea, M. T., Friedman, M. J., \& Engel, C. C. (2007). Posttraumatic stress disorder and cognitive behavioral therapy: In reply. JAMA, 297(24), 2695.

260. Kent, M., Davis, M. C., Stark, S. L., \& Stewart, L. A. (2011). A resilience-oriented treatment for posttraumatic stress disorder: Results of a preliminary randomized clinical trial. Journal of Traumatic Stress, 24(5), 591-595.

261. Paquette, M. (2008). The aftermath of war: Spiritual distress. Perspectives in Psychiatric Care, 44(3), 143-145.

262. Sautter, F. J., Glynn, S. M., Thompson, K. E., Franklin, L., \& Han, X. (2009). A couple-based approach to the reduction of PTSD avoidance symptoms: Preliminary findings. Journal of Marital and Family Therapy, 35(3), 343-349.

263. Dustin, D., Bricker, N., Arave, J., Wall, W., \& Wendt, G. (2011). The promise of river running as a therapeutic medium for veterans coping with post-traumatic stress disorder. Therapeutic Recreation Journal, 45(4), 326-340.

264. Ford, J. D., Greaves, D., Chandler, P., Thacker, B., Shaw, D., Sennhauser, S., \& Schwartz, L. (1997). Timelimited psychotherapy with Operation Desert Storm veterans. Journal of Traumatic Stress, 10(4), 655-664.

265. Rosenthal, J. Z., Grosswald, S., Ross, R., \& Rosenthal, N. (2011). Effects of transcendental meditation in veterans of Operation Enduring Freedom and Operation Iraqi Freedom with posttraumatic stress disorder: A pilot study. Military Medicine, 176(6), 626-630. 
266. Watson, C. G., Tuorila, J., Detra, E., Gearhart, L. P., \& Wielkiewicz, R. M. (1995). Effects of a Vietnam War memorial pilgrimage on veterans with posttraumatic stress disorder. Journal of Nervous and Mental Disease, 183(5), 315-319.

267. Gray, R. M., \& Liotta, R. F. (2012). PTSD: Extinction, reconsolidation, and the visual-kinesthetic dissociation protocol. Traumatology, 18(2), 3-16.

268. Johnston, J. (2012). The impact of yoga on military personnel with post traumatic stress disorder. Dissertation Abstracts International: Section B: The Sciences and Engineering, 73(4-B), 2532.

269. Stoller, C. C., Greuel, J. H., Cimini, L. S., Fowler, M. S., \& Koomar, J. A. (2012). Effects of sensory-enhanced yoga on symptoms of combat stress in deployed military personnel. American Journal of Occupational Therapy, 66(1), 59-68.

270. Braekkan, K. C. (2007). An acceptance and commitment therapy intervention for combat veterans with posttraumatic stress disorder: Preliminary outcomes of a controlled group comparison. Dissertation Abstracts International: Section B: The Sciences and Engineering, 67(12-B), 7365.

271. Ragsdale, K. G., Cox, R. D., Finn, P., \& Eisler, R. M. (Apr 1996). Effectiveness of short-term specialized inpatient treatment for war-related posttraumatic stress disorder: A role for adventure-based counseling and psychodrama. Journal of Traumatic Stress, 9(2), 269-283.

272. Thomas, M. K. (2004). Assessment of the effectiveness of anger management treatment in Vietnam veterans with posttraumatic stress disorder. Dissertation Abstracts International: Section B: Sciences and Engineering, 65(2-B), 1040.

273. Wright, T. P. (2003). The effectiveness of behavioral activation group therapy: Treating comorbid depression on a specialized inpatient posttraumatic stress disorder unit for combat veterans. Dissertation Abstracts International: Section B: Sciences and Engineering, 64(1-B), 436.

274. Leskin, G. A. (1996). Direct therapeutic exposure and posttraumatic stress disorder: Predicting change scores. Dissertation Abstracts International: Section B: Sciences and Engineering, 57(4-B), 2872.

275. Devilly, G. J., Spence, S. H., \& Rapee, R. M. (1998). Statistical and reliable change with eye movement desensitization and reprocessing: Treating trauma within a veteran population. Behavior Therapy, 29(3), 435-455.

276. Jensen, J. A. (1994). An investigation of eye movement desensitization and reprocessing (EMD/R) as a treatment for posttraumatic stress disorder (PTSD) symptoms of Vietnam combat veterans. Behavior Therapy, 25(2), 311325.

277. Lipke, H. J., \& Botkin, A. L. (1992). Case studies of eye movement desensitization and reprocessing (EMDR) with chronic post-traumatic stress disorder. Psychotherapy: Theory, Research, Practice, Training, 29(4), 591-595.

278. Albright, D. L., \& Thyer, B. (2010). EMDR is not an empirically supported treatment for combat-related PTSD ... yet: A response to Elisha C. Hurley, DMin, Colonel, USA (Retired). Behavioral Interventions, 25(4), 355-360.

279. Lee, C. W., \& Schubert, S. (2009). Omissions and errors in the Institute of Medicine's report on scientific evidence of treatment for posttraumatic stress disorder. Journal of EMDR Practice and Research, 3(1), 32-38.

280. Johnson, D. R., Lubin, H., \& Corn, B. (1999). Course of treatment during a cohort-based inpatient program for posttraumatic stress disorder. Group, 23(1), 19-35.

281. Ross, R. J., Gehrman, P., Cook, J. M., Harb, G. C., \& Gamble, G. M. (2009). Randomized controlled trial of imagery rehearsal for posttraumatic nightmares in Vietnam veterans. Sleep, 32, A348.

282. Bleich, A., Shalev, A., Shoham, S., Solomon, Z., \& Kotler, M. (1992). PTSD: Theoretical and practical considerations as reflected through Koach: An innovative treatment project. Journal of Traumatic Stress, 5(2), 265-271.

283. Watson, C. G., Tuorila, J. R., Vickers, K. S., Gearhart, L. P., \& Mendez, C. M. (1997). The efficacies of three relaxation regimens in the treatment of PTSD in Vietnam War veterans. Journal of Clinical Psychology, 53(8), 917-923.

284. Gamito, P., Oliveira, J., Morais, D., Oliveira, S., Duarte, N., Saraiva, T., \& Rosa, P. (2009). Virtual reality therapy contolled study for war veterans with PTSD: Preliminary results. Annual Review of CyberTherapy and Telemedicine, 7(1), 269-272. 